\title{
The Effect of Phosphate Rocks on Spring Barley Shoot Yield in a Pot Trial
}

\author{
${ }^{1}$ P. CSATHÓ, ${ }^{1}$ E. OSZTOICS, ${ }^{1} \mathrm{~J}$. CSILLAG,${ }^{2}$ T. LENGYEL, ${ }^{2}$ L. GONDA, \\ ${ }^{1}$ L. RADIMSZKY, ${ }^{1}$ G. BACZÓ, ${ }^{1}$ M. MAGYAR, ${ }^{1}$ K. R. VÉGH, ${ }^{1}$ M. KARÁTSONYI, \\ ${ }^{1}$ T. TAKÁCS, ${ }^{1}$ A. LUKÁCS and ${ }^{1}$ T. NÉMETH \\ ${ }^{1}$ Research Institute for Soil Science and Agricultural Chemistry of the Hungarian \\ Academy of Sciences, Budapest and ${ }^{2}$ Nitrogénmüvek Ltd., Pétfürdő (Hungary)
}

\section{Introduction}

Phosphate rocks are of either igneous or sedimentary origin. Reactive sedimentary phosphate rocks are suitable for direct field application as P fertilizers on moderately or strongly acidic soils (KHASAWNEH \& DOLL, 1978). The dissolution of phosphate rock depends mainly on the phosphate rock's properties (chemical reactivity, specific surface, particle size), as well as on soil characteristics, climate, etc. The solubility of phosphate rocks in soil is influenced favourably by low available $\mathrm{P}$, exchangeable $\mathrm{Ca}, \mathrm{pH}(<\mathrm{pH} 6)$ and base saturation, high cation exchange capacity, OM content, and satisfactory water supply (HAMMOND et al., 1986). The assessment of the agronomic effectiveness of phosphate rocks as $\mathrm{P}$ fertilizers is based upon a comparison to water soluble $P$ fertilizers.

Total $\mathrm{P}$ content is not an indicator of the agronomic effectiveness of phosphate rock. The most informative property of phosphate rock in relation to its agronomic performance is solubility (CHIEN, 1993). The chemical reactivity of phosphate rocks can be estimated by the solubility of their P content in different extractants (KHASAWNEH \& DOLL, 1978; CHIEN, 1993). Mostly neutral ammonium citrate (USA, Australia), 2\% citric acid (Brasil) and 2\% formic acid (Europe) are used as solvents. Classification of phosphate rocks as reactive and non-reactive ones according to their solubility, is not unified all over the world. In Europe, for example, phosphate rocks with more than $55 \%$ of total $\mathrm{P}$ dissolved in $2 \%$ formic acid are considered reactive.

The objective of the present study was: 1 . to determine the $\mathrm{P}$ solubility of six phosphate rocks, using different solvents; 2 . to investigate the effect of different phosphate rocks, single superphosphate (SSP), and SSP+Ca treatment on soil available $\mathrm{P}$ contents, as well as on the shoot yields of tillering-stage spring barley (Hordeum vulgare L.) grown in a pot trial. Results obtained with red clover (Trifolium pratense L.) were published by OsZTOICS et al. (2005b).

Correspondence to: PÉTER CSATHÓ, Research Institute for Soil Science and Agricultural Chemistry of the Hungarian Academy of Sciences, H-1022 Budapest, Herman Ottó út 15. Hungary. E-mail: csatho@rissac.hu 


\section{Materials and Methods}

\section{Laboratory experiment}

In both the laboratory and pot experiment all phosphate rocks were applied with $<160 \mu \mathrm{m}$ particle size, as within this fraction differences in particle size do not affect their agronomic effectiveness (HAMMOND et al., 1986).

Methods for evaluating the chemical reactivity of the phosphate rocks were: 1 . Extraction with 2\% formic acid; 2. Extraction with 2\% citric acid; 3. Extraction with neutral ammonium citrate, first extraction (ISO 7497-1984/E; OJEC, 1977. No. L 213/5.).

Total $\mathrm{P}$ content of $\mathrm{P}$ sources and soils were determined by inductively coupled plasma emission spectrometry (ICP) after microwave digestion with cc. $\mathrm{HNO}_{3}+$ $\mathrm{H}_{2} \mathrm{O}_{2}$ in teflon bomb.

\section{Greenhouse experiment}

A greenhouse experiment was conducted with spring barley to determine the comparative effectiveness of six phosphate rocks applied directly on a Lamellic Arenosol with sand soil texture, strongly acidic and low in available P (Nyírlugos, Hungary), and on a Haplic Luvisol with clay loam texture, also strongly acidic and very low in available $\mathrm{P}$ (Ragály, Hungary). The main physical and chemical properties of the untreated soils are given in Table 1.

Table 1

Chemical and physical properties of the soils used in the greenhouse experiment

\begin{tabular}{|c|c|c|}
\hline Soil property & $\begin{array}{c}\text { Acidic sandy soil } \\
\text { (Nyírlugos) }\end{array}$ & $\begin{array}{c}\text { Acidic clay loam soil } \\
\text { (Ragály) }\end{array}$ \\
\hline $\mathrm{pH}\left(\mathrm{H}_{2} \mathrm{O}\right)\left(1: 2.5\right.$ soil: $\left.\mathrm{H}_{2} \mathrm{O}\right)$ & 5.0 & 5.7 \\
\hline $\mathrm{pH}(\mathrm{KCl})(1: 2.5$ soil: $1 M \mathrm{KCl})$ & 3.8 & 4.5 \\
\hline Clay+silt $(<0.02 \mathrm{~mm}), \%$ & 5.0 & 59.8 \\
\hline Clay $(<0.002 \mathrm{~mm}), \%$ & 2.2 & 26.6 \\
\hline Total $\mathrm{P}, \mathrm{mg} \cdot \mathrm{kg}^{-1}$ & 300 & 480 \\
\hline AL- $\mathrm{P}_{2} \mathrm{O}_{5}, \mathrm{mg} \cdot \mathrm{kg}^{-1}$ (EGNÉR et al., 1960) & 53.6 & 17.3 \\
\hline LE-P, $\mathrm{mg} \cdot \mathrm{kg}^{-1}$ (LAKANEN \& ERVIÖ, 1971) & 60.7 & 14.9 \\
\hline Olsen-P, mg.kg ${ }^{-1}$ (OLSEN et al., 1954) & 16.2 & 6.3 \\
\hline Water soluble-P, $\mathrm{mg} \cdot \mathrm{kg}^{-1}$ (SARKADI, 1982) & 8.5 & 3.1 \\
\hline $\begin{array}{l}\text { Exchangeable } \mathrm{Ca}, \mathrm{Mg}, \mathrm{CEC} \text { (ammonium } \\
\text { acetate method), } \mathrm{cmol}_{\mathrm{c}} \cdot \mathrm{kg}^{-1}\end{array}$ & & \\
\hline Exchangeable $\mathrm{Ca}$ & 0.8 & 11.6 \\
\hline Exchangeable $\mathrm{Mg}$ & 0.1 & 3.1 \\
\hline Cation exchange capacity (CEC) & 3.0 & 19.6 \\
\hline Hydrolytic acidity, $\%\left(\mathrm{y}_{1}\right)$ & 11 & 17 \\
\hline Exchangeable acidity $\left(\mathrm{y}_{2}\right)$ & 3.7 & 0 \\
\hline Soil organic matter, \% (OM) (BUZÁs, 1988) & 0.6 & 3.4 \\
\hline
\end{tabular}


The treatments of the experiment set up in split-split plot design included three replicates of each of the phosphate rocks, single superphosphate (SSP) (Linz, Austria), and $\mathrm{SSP}+\mathrm{CaCO}_{3}$ mixed into the soil at rates of 100,400 and $1600 \mathrm{mg}$ total $\mathrm{P}_{2} \mathrm{O}_{5} \cdot \mathrm{kg}^{-1}$ soil, plus a NK treatment without $\mathrm{P}$. In the $\mathrm{SSP}+\mathrm{CaCO}_{3}$ treatment 1910 and $4960 \mathrm{mg} \mathrm{CaCO}{ }_{3} \cdot \mathrm{kg}^{-1}$ soil was applied to the acidic sandy soil and acidic clay loam soil, respectively, to neutralize acidity (FILEP, 1999). All pots received 100 $\mathrm{mg} \mathrm{N}$ and $200 \mathrm{mg} \mathrm{K} \mathrm{O}_{2} \cdot \mathrm{kg}^{-1}$ soil for adequate $\mathrm{N}$ and $\mathrm{K}$ supply. All P sources and the $\mathrm{N}$ and $\mathrm{K}$ fertilizers were mixed into each pot containing $1.6 \mathrm{~kg}$ soil on the day the spring barley test crop was planted. Moisture levels were initially maintained at about $60 \%$ of field capacity, after which soils were watered according to the requirement of plants during the growing period. The weight of air-dried shoots was determined for each pot. The results from the tillering-stage cut are evaluated in the present paper. The second half of the trial was harvested at flowering stage, but due to paper volume limitations, these results are not included. Available soil $\mathrm{P}$ was estimated by the Ammonium-Lactate (AL) (EGNER et al., 1960), Lakanen-Erviö (LE) (LAKANEN \& ERVIÖ, 1971), Olsen (OlSEN et al., 1954), Bray1 (BRAY \& KURTZ, 1945) and water (SARKADI, 1982) methods.

\section{Results and Discussion}

\section{Laboratory experiment}

Specific surface, $\mathrm{CaCO}_{3}$ content, total $\mathrm{P}$ and the reactivity scales of the investigated six phosphate rocks - originating from Algeria (ALG), North Florida (FLO), North Carolina (NCA), Senegal (SEN), Morocco (MO) and Hyperphosphate (HYP) - as measured by the chemical extractions are shown in Table 2. Among the phos-

Table 2

Properties and solubility tests (reactivity scales) of the phosphate rocks (PR) $(<160 \mu \mathrm{m})$ as measured by conventional reagents (OszTOICS et al., 2005a,b)

\begin{tabular}{|c|c|c|c|c|c|c|c|c|c|}
\hline \multirow{3}{*}{$\begin{array}{l}\text { Phos- } \\
\text { phate } \\
\text { rock }\end{array}$} & \multicolumn{3}{|c|}{ Properties } & \multicolumn{6}{|c|}{ Soluble $\mathrm{P}_{2} \mathrm{O}_{5} \%$, extracted by } \\
\hline & \multirow{2}{*}{$\begin{array}{l}\text { Specific } \\
\text { surface, } \\
\mathrm{m}^{2} \cdot \mathrm{g}^{-1}\end{array}$} & \multirow{2}{*}{$\begin{array}{c}\mathrm{CaCO}_{3} \\
\%\end{array}$} & \multirow{2}{*}{$\begin{array}{l}\text { Total } \\
\mathrm{P}_{2} \mathrm{O}_{5}, \\
\%\end{array}$} & \multicolumn{2}{|c|}{$2 \%$ formic acid } & \multicolumn{2}{|c|}{$2 \%$ citric acid } & \multicolumn{2}{|c|}{$\begin{array}{c}\text { neutral } \mathrm{NH}_{4}^{+} \\
\text {citrate }\end{array}$} \\
\hline & & & & $\begin{array}{l}\text { \% of } \\
\text { PR }\end{array}$ & $\begin{array}{l}\% \text { of } \\
\text { total P }\end{array}$ & $\begin{array}{l}\% \text { of } \\
\text { PR }\end{array}$ & $\begin{array}{l}\% \text { of } \\
\text { total P }\end{array}$ & $\begin{array}{l}\% \text { of } \\
\text { PR }\end{array}$ & $\begin{array}{l}\% \text { of } \\
\text { total P }\end{array}$ \\
\hline ALG & 14.2 & 18.3 & 27.5 & 17.6 & 63.9 & 10.8 & 39.4 & 8.2 & 29.8 \\
\hline FLO & 12.7 & 6.9 & 25.4 & 6.7 & 26.3 & 6.5 & 25.6 & 2.7 & 10.6 \\
\hline NCA & 20.0 & 12.8 & 23.8 & 17.9 & 75.2 & 11.6 & 48.9 & 5.1 & 21.4 \\
\hline SEN & 5.7 & 4.3 & 33.0 & 9.5 & 28.8 & 8.6 & 26.0 & 2.5 & 7.6 \\
\hline MOR & 12.0 & 14.4 & 26.1 & 15.2 & 58.2 & 9.7 & 37.3 & 3.1 & 11.9 \\
\hline HYP & 15.4 & 13.3 & 22.5 & 14.7 & 65.2 & 10.9 & 48.3 & 5.0 & 22.2 \\
\hline
\end{tabular}

Note: ALG: Algeria; FLO: North Florida; NCA: North Carolina; SEN: Senegal; MOR: Morocco; HYP: Hyperphosphate 
phate rocks ALG, NCA and HYP had the highest P solubility. On the other hand, the less P soluble phosphate rocks were SEN and FLO (Table 2).

\section{The effect of $P$ sources and rates on soil available $P$ contents}

After completing the pot trial, the dissolution of the phosphate rocks in soil was assessed by water, Olsen, Bray1, Lakanen-Erviö (LE), and ammonium lactate (AL) soluble P tests (Table 3). In Hungary the AL method has been used officially as the extractant for assessing soil $\mathrm{P}$ availability in the case of using water soluble $\mathrm{P}$ sources as P fertilizers (EGNER et al., 1960). The applicability of the AL method for determining the basic reactive phosphate rocks as P sources was also studied in the pot trial.

On the acidic sandy soil (Nyírlugos), over all $\mathrm{P}$ sources, as compared to the NK control, the $1600 \mathrm{mg} \cdot \mathrm{kg}^{-1}$ total $\mathrm{P}_{2} \mathrm{O}_{5}$ dose caused a five-fold increase in the $\mathrm{H}_{2} \mathrm{O}-\mathrm{P}$ and Olsen-P, a 15-fold increase in the Bray1, and a 23-24-fold increase in the LE-P and AL-P values. The same methods on the acidic clay-loam soil (Ragály) resulted in 8-9, 20 and 46-64 times higher values, respectively (Table 3).

When low water-soluble fertilizers like phosphate rocks are applied, soil testing using strongly acidic $\mathrm{AL}(\mathrm{pH}=3.75)$, or $\mathrm{LE}(\mathrm{pH}=4.65)$ extractants can dissolve a substantial amount of the unsolubilized phosphate rock in the soil. Therefore they can overestimate the available P from PR-treated soils as compared to soils treated with SSP. In an incubation experiment with Algerian phosphate rock and SSP, OszTOICS et al. (2003) obtained similar results with the AL extractant.

\section{The effect of $P$ sources and rates on spring barley shoot yields}

In the case of both soils, the higher the phosphate rock solubility was in formic acid, citric acid or neutral ammonium citrate, the higher the $\mathrm{P}$ responses obtained in spring barley were (Table 4). On the average of the P forms and doses, spring barley shoot yield was $95 \%$ higher on colloid-rich acidic clay loam soil $\left(3.69{\left.\mathrm{~g} \cdot \mathrm{pot}^{-1}\right)}^{-1}\right.$ than on colloid-poor acidic sandy soil $\left(1.90 \mathrm{~g} \cdot \mathrm{pot}^{-1}\right)$. In the acidic sandy soil, on the average of $\mathrm{P}$ forms, as an effect of the $1600 \mathrm{mg}$ total $\mathrm{P}_{2} \mathrm{O}_{5} \cdot \mathrm{kg}^{-1} \mathrm{P}$-dose, spring barley yields were 4.4-times greater, as compared to the NK treatment, while in the acidic clay loam soil the yield values were 4.9 -times higher.

On the average of the $\mathrm{P}$ doses, in the case of the acidic sandy soil (Nyírlugos), the highest spring barley shoot yields (2.25 and $\left.2.23 \mathrm{~g} \cdot \mathrm{pot}^{-1}\right)$ were obtained, among the phosphate rocks, with the highly soluble Algerian (ALG) and the Hyperphosphate (HYP) PRs. Treatments with the Senegal and North Florida phosphate rocks - having the lowest $\mathrm{P}$ solubility - produced the smallest average spring barley shoot yields $\left(0.88\right.$ and $\left.0.92 \mathrm{~g} \cdot \mathrm{pot}^{-1}\right)$. Spring barley grown on the acidic clay loam soil (Ragály) gave the highest average shoot yields $\left(4.25\right.$ and $\left.3.81 \mathrm{~g} \cdot \mathrm{pot}^{-1}\right)$ in the treatments, among the phosphate rocks, with PRs from Algeria and North Carolina. A previous study (NÉMETH et al., 1996; OsZTOICS et al., 2001) also showed that on strongly acidic soils from the Carpathian Basin, Algerian phosphate rock could be considered a P source as effective as SSP. When all of the P sources were taken into 


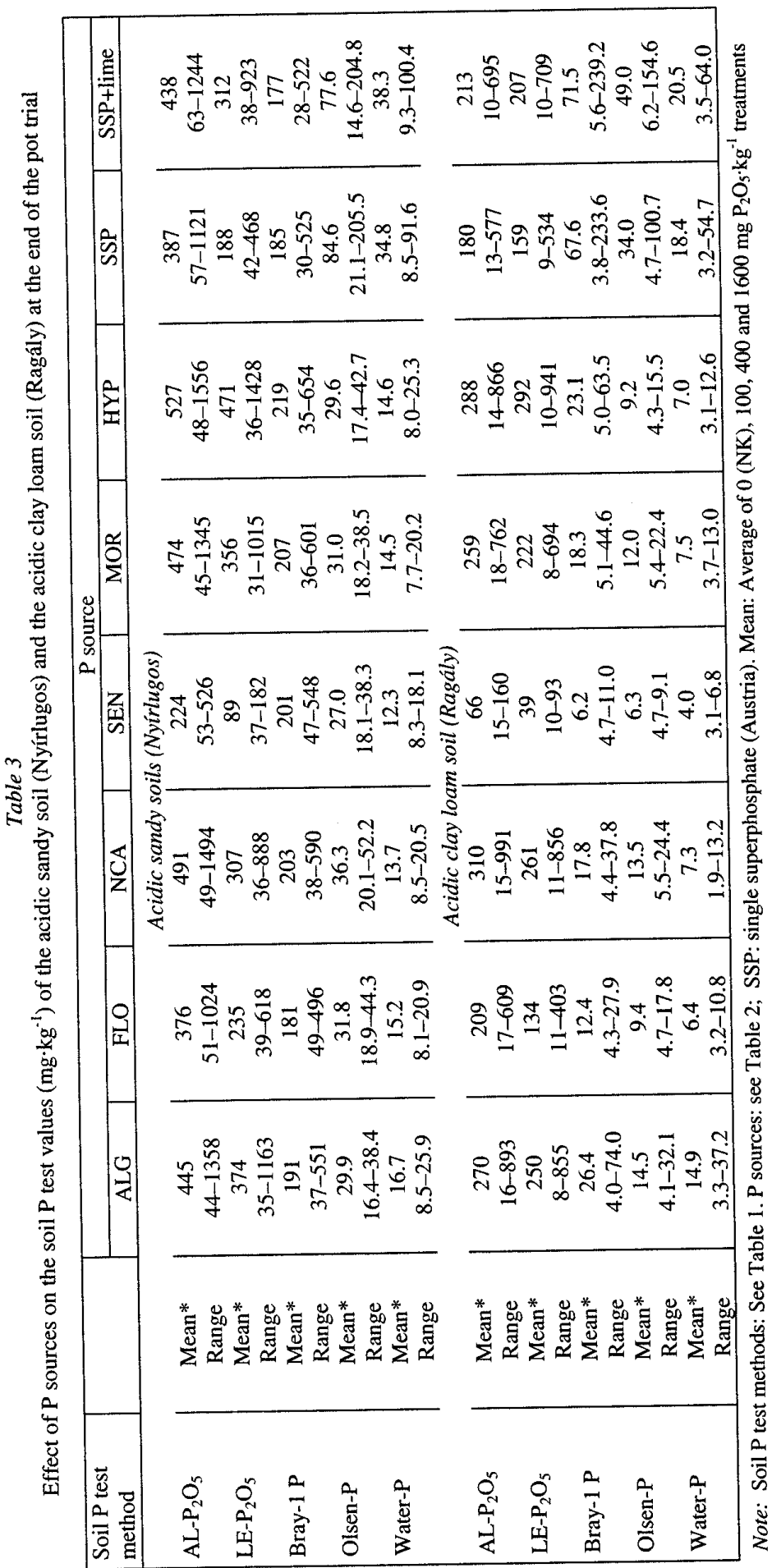


Table 4

Shoot weights $\left(\mathrm{g} \cdot \operatorname{pot}^{-1}\right)$ of spring barley grown in the pot experiment with acidic sandy soil (Nyírlugos) and acidic clay loam soil (Ragály) treated with different P sources (at the beginning of shooting)

\begin{tabular}{|c|c|c|c|c|c|c|c|c|c|c|}
\hline \multirow{2}{*}{ Treatments } & \multicolumn{8}{|c|}{$\mathrm{P}$ source } & \multirow{2}{*}{$\mathrm{LSD}_{5 \%}$} & \multirow{2}{*}{ Mea } \\
\hline & ALG & FLO & $\mathrm{NCA}$ & SEN & MOR & HYP & SSP & $\mathrm{SSP}+\mathrm{Ca}$ & & \\
\hline \multicolumn{11}{|c|}{ A. Acidic sandy soil (Nyírlugos) } \\
\hline $\mathrm{NKP}_{0}$ & 0.51 & 0.47 & 0.48 & 0.45 & 0.53 & 0.50 & 0.36 & 2.68 & & 0.75 \\
\hline $\mathrm{NKP}_{100}$ & 1.26 & 0.67 & 0.97 & 0.64 & 0.69 & 1.13 & 0.74 & 3.94 & 0.67 & 1.25 \\
\hline $\mathrm{NKP}_{400}$ & 3.00 & 0.95 & 1.68 & 0.76 & 2.52 & 2.94 & 2.06 & 4.43 & & 2.29 \\
\hline $\mathrm{NKP}_{1600}$ & 4.23 & 1.59 & 2.85 & 1.67 & 3.74 & 4.36 & 3.68 & 4.19 & & 3.29 \\
\hline $\mathrm{LSD}_{5 \%}$ & & & & & 0.67 & & & & & 0.24 \\
\hline $\mathrm{M}$ & 2.25 & 0.92 & 1.50 & 0.88 & 1.87 & 2.23 & 1.71 & 3.81 & 0.33 & 1.90 \\
\hline \multicolumn{11}{|c|}{ B. Acidic clay loam soil (Ragály) } \\
\hline & 1.16 & 1.08 & 1.28 & 1.03 & 1.03 & 0.98 & 1.11 & 1.26 & & 1.12 \\
\hline 100 & 4.11 & 1.85 & 2.47 & 1.12 & 2.55 & 2.87 & 6.92 & 4.56 & 1.11 & 3.31 \\
\hline $\mathrm{NKP}_{400}$ & 5.64 & 2.86 & 5.18 & 1.80 & 5.34 & 4.65 & 6.29 & 7.10 & & 4.86 \\
\hline $\mathrm{NKP}_{1600}$ & 6.08 & 4.62 & 6.31 & 3.20 & 5.93 & 5.12 & 6.20 & 6.32 & & 5.47 \\
\hline & & & & & 1.11 & & & & & 0.39 \\
\hline Mean & 4.25 & 2.60 & 3.81 & 1.79 & 3.71 & 3.41 & 5.13 & 4.81 & 0.55 & 3.69 \\
\hline
\end{tabular}

Note: ALG: Algeria; FLO: North Florida; NCA: North Carolina; SEN: Senegal; MOR: Morocco; HYP: Hyperphosphate; SSP: single superphosphate (Linz, Austria)

account it was found that on the acidic sandy soil (Nyírlugos) the single superphosphate and lime $\left(\mathrm{SSP}+\mathrm{CaCO}_{3}\right)$ treatment $\left(3.81 \mathrm{~g} \cdot \mathrm{pot}^{-1}\right)$, on the acidic clay loam soil (Ragály) the $\mathrm{SSP}$ and $\mathrm{SSP}+\mathrm{CaCO}_{3}$ treatments (5.13 and $4.81 \mathrm{~g} \cdot$ pot $^{-1}$ ) gave the highest spring barley shoot yields (Table 4).

\section{Relationship between phosphate rock solubility and spring barley shoot yields}

In the case of both soils only a weak correlation $\left(\mathrm{r}^{2}=0.47-0.53\right)$ was established between the total added $\mathrm{P}$ of the six phosphate rock treatments and spring barley

\section{Table 5}

Correlation coefficients $\left(\mathrm{r}^{2}\right)$ between the total, and "soluble" $\mathrm{P}$ amounts added and tillering stage shoot yield of spring barley grown in a pot experiment set up with acidic sandy (Nyírlugos) and acidic clay loam (Ragály) soils and six phosphate rock treatments $(\mathrm{y}=\mathrm{a} \ln (\mathrm{x})+\mathrm{b} ; \mathrm{n}=18$, excluding the NK treatments $)$

\begin{tabular}{|l|c|c|}
\hline \multicolumn{1}{|c|}{ Solvent } & $\begin{array}{c}\text { Acidic sandy soil } \\
\text { (Nyírlugos) }\end{array}$ & $\begin{array}{c}\text { Acidic clay loam soil } \\
\text { (Ragály) }\end{array}$ \\
\hline $65 \mathrm{ww} \% \mathrm{HNO}_{3}+30 \mathrm{ww}_{\mathrm{N}} \mathrm{H}_{2} \mathrm{O}_{2}$ (total) & 0.5259 & 0.4727 \\
$2 \%$ formic acid & 0.7277 & 0.7209 \\
$2 \%$ citric acid & 0.6556 & 0.6199 \\
Neutral $\mathrm{NH}_{4}^{+}$-citrate & 0.7421 & 0.7510 \\
\hline
\end{tabular}


$\mathrm{P}$ responses. If the $\mathrm{P}$ solubility of the phosphate rocks was also taken into consideration, the correlation between the added formic acid, citric acid or neutral ammonium citrate soluble $\mathrm{P}$ amounts and spring barley responses became much stronger (Table 5). The strongest correlation was obtained when the amount of $\mathrm{P}$ added was based on the neutral ammonium citrate soluble $\mathrm{P}\left(\mathrm{r}^{2}=0.74-0.75\right)$ (Table 5). Similar results were also obtained by CHIEN and HAMMOND (1978), LÉON et al. (1986), and ZAHARAH and SHARIFUDDIN (2002).

Table 6

Relative agronomic effectiveness (RAE, \%) of the phosphate rocks applied to the acidic sandy soil (Nyírlugos) and acidic clay loam soil (Ragály) in the spring barley pot experiment

\begin{tabular}{|l|c|c|c||c|c|c|}
\hline \multirow{3}{*}{ P source } & \multicolumn{2}{|c||}{ Acidic sandy soil (Nyírlugos) } & \multicolumn{3}{c|}{ Acidic clay loam soil (Ragály) } \\
\cline { 2 - 7 } & \multicolumn{2}{|c||}{$\mathrm{P}$ applied, mg total $\mathrm{P}_{2} \mathrm{O}_{5} \cdot \mathrm{kg}^{-1}$} & \multicolumn{2}{|c|}{$\mathrm{P}$ applied, mg total $\mathrm{P}_{2} \mathrm{O}_{5} \cdot \mathrm{kg}^{-1}$} \\
\cline { 2 - 7 } & 100 & 400 & 1600 & 100 & 400 & 1600 \\
\hline ALG & 289 & 160 & 117 & 52 & 87 & 98 \\
FLO & 73 & 30 & 35 & 13 & 34 & 69 \\
NCA & 183 & 76 & 74 & 24 & 79 & 102 \\
SEN & 61 & 18 & 37 & 0 & 14 & 41 \\
MOR & 79 & 129 & 102 & 25 & 82 & 95 \\
HYP & 241 & 156 & 121 & 31 & 69 & 79 \\
SSP+Ca & 465 & 111 & 47 & 57 & 112 & 99 \\
\hline
\end{tabular}

Note: P sources: ALG: Algeria; FLO: North Florida; NCA: North Carolina; SEN: Senegal; MOR: Morocco; HYP: Hyperphosphate; SSP: single superphosphate (Linz, Austria)

The relative agronomic effectiveness (RAE) of phosphate rocks was also evaluated, in which the spring barley shoot yields of phosphate rock treatments was compared to yields obtained with single superphosphate treatment (SSP) (Table 6):

$$
R A E \%=\left(\frac{X_{1}-X_{0}}{X_{2}-X_{0}}\right) \cdot 100
$$

where: $\mathrm{X}_{1}=$ spring barley shoot weight at a given $\mathrm{P}$ level with phosphate rock application; $\mathrm{X}_{2}=$ spring barley shoot weight at the same $\mathrm{P}$ level with single superphosphate (SSP) application; $\mathrm{X}_{0}=$ spring barley shoot weight in the NK plot without P. The phosphate rock from Senegal (SEN) had the lowest effectiveness among the studied phosphate rocks. The relative agronomic effectiveness of the Algerian (ALG) phosphate rock was almost comparable to that of the $\mathrm{SSP}+\mathrm{CaCO}_{3}$ treatment.

\section{Correlation between the soil $P$ test values and spring barley shoot yields}

When phosphate rocks were applied as $\mathrm{P}$ source, the comparison of soil test $\mathrm{P}$ methods showed a different picture on the two soils. In the case of the acidic sandy soil (Nyírlugos) the highest correlation coefficients with spring barley P response were given by the strongly acid LE-P $\left(r^{2}=0.83\right)$ and AL-P $\left(r^{2}=0.74\right)$ tests, while 


\section{Table 7}

Correlation coefficients $\left(\mathrm{r}^{2}\right)$ between the soil $\mathrm{P}$ test values and air-dry shoot weights of spring barley grown in a pot experiment set up with acidic sandy soil (Nyírlugos) and acidic clay loam soil (Ragály) and six phosphate rock treatments $(\mathrm{y}=\mathrm{a} \ln (\mathrm{x})+\mathrm{b} ; \mathrm{n}=24$, including the NK treatments $)$

\begin{tabular}{|l|c|c|}
\hline \multicolumn{1}{|c|}{ Correlation between } & $\begin{array}{c}\text { Acidic sandy soil } \\
\text { (Nyírlugos) }\end{array}$ & $\begin{array}{c}\text { Acidic clay loam soil } \\
\text { (Ragály }\end{array}$ \\
\hline AL-P and shoot weight & 0.7364 & 0.8092 \\
LE-P and shoot weight & 0.8267 & 0.8372 \\
Olsen-P and shoot weight & 0.4878 & 0.8819 \\
Water-P and shoot weight & 0.6860 & 0.8332 \\
Bray1-P and shoot weight & 0.6459 & 0.8799 \\
\hline
\end{tabular}

for the acidic clay loam soil (Ragály) the highest correlation coefficients were obtained with the Olsen-P $\left(\mathrm{r}^{2}=0.88\right)$ and Bray1-P $\left(\mathrm{r}^{2}=0.88\right)$ methods (Table 7).

On the acidic clay loam soil the revealed results also confirmed that - similarly to the Bray-2 and double acid methods -the AL-method is not or is less applicable for the soil testing of available P from phosphate rock treated soils than the Olsen or Bray1 method (HAMMOND et al., 1986).

\section{Summary}

Depending on their origin, sedimentary phosphate rocks (PRs) may differ in their P solubility, and, as a consequence, in their agronomic effectiveness. The effect of six phosphate rocks (PR) - originating from Algeria (ALG), North Florida (FLO), North Carolina (NCA), Senegal (SEN) Morocco (MOR) and Hyperphosphate (HYP) with various $P$ solubility (evaluated by $2 \%$ formic acid, $2 \%$ citric acid, and neutral ammonium citrate) - as well as single superphosphate (SSP) and superphosphate + lime (SSP $+\mathrm{Ca}$ ) (each P source on $4 \mathrm{P}$ levels, with doses of 0 , 100,400 and $1600 \mathrm{mg} \mathrm{P}_{2} \mathrm{O}_{5} \cdot \mathrm{kg}^{-1}$ soil) on the shoot yield of tillering stage spring barley, soil available $\mathrm{P}$ (i.e. $\mathrm{H}_{2} \mathrm{O}$, Olsen, Bray1, Lakanen-Erviö (LE) and ammonium lactate (AL) extractable $\mathrm{P}$ contents) were studied in pot experiments set up with acidic sandy soil (Nyírlugos, Hungary) and acidic clay loam soil (Ragály, Hungary), both with low $\mathrm{P}$ supplies.

The average spring barley shoot yield at the beginning of shooting was $95 \%$ higher on the colloid-rich acidic $\left(\mathrm{pH}_{\mathrm{KCl}}\right.$ : 4.5) clay loam soil than on the colloid-poor acidic $\left(\mathrm{pH}_{\mathrm{KCl}}\right.$ : 3.8) sandy soil. The differences in the solubility of phosphate rocks showed close correlation to the differences in $\mathrm{P}$ responses. On both soils, the correlation between total PR-P added and P responses in spring barley shoot yield was much weaker than that between neutral ammonium citrate soluble PR-P added and $\mathrm{P}$ responses in spring barley shoot yield. When phosphate rocks were applied as $\mathrm{P}$ sources, the comparison of soil test $\mathrm{P}$ methods showed a different picture on the two soils. In the case of the acidic sandy soil (Nyírlugos), the strongly acid LE-P $\left(\mathrm{r}^{2}=\right.$ 
$0.83)$ and AL-P $\left(r^{2}=0.74\right)$ tests gave the highest correlation coefficients with spring barley responses to $\mathrm{P}$, while on the acidic clay loam soil (Ragály) these were achieved by the Olsen-P $\left(r^{2}=0.88\right)$ and Bray1-P $\left(r^{2}=0.88\right)$ methods.

The presented study was financially supported by the Hungarian National Scientific Research Fund (OTKA) under Grant No. T 038046.

Key words: sedimentary phosphate rocks, soil $\mathrm{P}$ tests, $\mathrm{P}$ solubility of phosphate rocks, relative agronomic effectiveness

\section{References}

BRAY, R. H. \& KURTZ, L. T., 1945. Determination of total, organic and available forms of phosphorus in soils. Soil Sci. 59. 39-45.

BuZÁs, I. (Ed.), 1988. Manual of Soil and Agrochemical Analysis. II. (In Hungarian) Mezőgazda Kiadó. Budapest.

CHIEN, S. H., 1993. Solubility assessment for fertilizer containing phosphate rock. Fert. Res. 35. 93-99.

ChIEN, S. H. \& HAMmond, L. L., 1978. A comparison of various laboratory methods for predicting the agronomic potential of phosphate rocks for direct application. Soil Sci. Soc. Am. J. 42. 935-939.

EgNeR, H., RIeHM, H. \& Domingo, W. R., 1960. Untersuchungen über die chemische Bodenanalyse als Grundlage für die Beurteilung des Nahrstoffzustandes der Böden. II. Lantbr. Högsk. Ann. 26. 199-215.

FiLEP, Gy. 1999. Soil Chemistry. Processes and Constituents. Akadémiai Kiadó. Budapest.

Hammond, L. L., Chien, S. H. \& Mokwunye, A. U., 1986. Agronomic value of unacidulated and partially acidulated phosphate rocks indigenous to the tropics. Adv. Agron. 40. 89-140.

International Standard. Fertilizers - Extraction of phosphates soluble in mineral acids. Ref. No. The International Organization for Standardization (ISO) 7497-1984 (E.). 1984.

Khasawneh, F. E. \& Doll, E. C., 1978. The use of phosphate rock for direct application. Adv. Agron. 30. 159-206.

LAKANEN, E. \& ERVIÖ, R., 1971. A comparison of eight extractants for the determination of plant available micronutrients in soils. Acta Agr. Fenn. 123. 223-232.

LÉON, L. A., Fenster, W. E. \& HAMmOND, L. L., 1986. Agronomic potential of eleven phosphate rocks from Brazil, Colombia, Peru, and Venezuela. SSSA. Proc. 50. 798-802.

NÉMETH, T., OszToICs, E. \& BACZÓ, G., 1996. Effect of different P-fertilizer sources on spring barley in a pot experiment with six acid soils. In: Soil Fertility and Fertilizer Management. Proc. $9^{\text {th }}$ Int. Symposium of CIEC (Eds.: Welte, E. \& SzABOLCS, I.) 99-106. CIEC. Goettingen. 
Olsen, S. R. et al., 1954. Estimation of Available Phosphorus in Soils by Extraction with Sodium Bicarbonate. US Dept. Agric. Circular No. 939. USDA. Washington, D. C.

Official Journal of the European Communities, No. L 213/5. Annex II., 22. 08.77. Methods for the Analysis of Fertilizers. 1977, 62-77.

OszTOICS, E. et al., 2001. Studies on the effect of Algerian rock phosphate and superphosphate. II. Effect of phosphorus fertilizers on the yield and phosphorus content of red clover in pot experiments. (In Hungarian) Agrokémia és Talajtan. 50. $247-$ 266.

OszTOICS, E. et al., 2003. Comparison of the effect of phosphate rock and superphosphate in acid soils of Hungary: incubation and pot experiment. In: Proc. CIEC $13^{\text {th }}$ Int. Symp. of Fertilizers. (Eds: HERA, C. et al.) 433-440. Braunschweig-Bucharest - Budapest-Gent.

OszTOICS, E. et al., 2005a. Analysis of the agronomic efficiency of rock phosphate in a pot experiment. I. Laboratory evaluation of rock phosphates. (In Hungarian) Agrokémia és Talajtan. 54. 341-358.

OszTOICS, E. et al., 2005b. Effect of five phosphate rocks on red clover (Trifolium pratense L.) yield in pot trial. Commun. Soil Sci. Plant Anal. 36. (In press)

SARKADI, J., 1982. Opredelenye „vodorastvorimogo“ fosfora. In: Agrochemische Methoden für die Untersuchung des Phosphathaushaltes des Böden: Methodensammlung. 1-13. Ak. der Landw. DDR. IPE. Jena

Zaharah, A. R. \& Sharifuddin, H. A. H., 2002. Phosphorus availability in acid tropical soil amended with phosphate rocks. In: Assessment of Soil Phosphorus Status and Management of Phosphatic Fertilisers to Optimise Crop Production. IAEA-TECDOC-1272. 294-302. IAEA. Vienna. 